\title{
Recenzja: Stownik biograficzny kobiet kultury. Białystok i województwo podlaskie, cz. I i II, Białystok 2017, 2018, Wydawnictwo Humanica
}

https://doi.org/10.34739/clit.2021.15.26

Na temat kobiet, ich ról w świecie, życiu społecznym i kulturze powiedziano już niemało. Tematykę tę podejmowało wielu wybitnych naukowców, humanistów w rozmaitych okresach historycznych. Różnorodne odsłony/portrety kobiet to obszar tak inspirujący, jak i wielowątkowy, rozległy badawczo, eksponujący wiele złożonych odniesień i płaszczyzn penetracji. Jedną z nich ujawnia Stownik biograficzny kobiet kultury. Białystok i województwo podlaskie, cz. I i II, wydany w Białymstoku w 2017 i 2018 roku, pod merytoryczną koncepcją Małgorzaty Dajnowicz. Publikacja jest zbiorem życiorysów kobiet ze szczególnym uwzględnieniem wątków ich aktywności kulturowej, wkładu w rozwój dziedzictwa narodowego/ kulturowego, głównie z obszaru Białegostoku i województwa podlaskiego. $\mathrm{Na}$ słownik składają się biogramy poszczególnych niewiast, ułożone w porządku chronologicznym. W opisie wzięto pod uwagę życie i działalność, wkład w kulturę, szczególnie we wskazanym regionie. Na podkreślenie zasługuje fakt, iż w publikacji zrezygnowano ze słownikowego układu całości na rzecz merytoryczną, a więc ukazanie na przestrzeni dziejów przemian w działalności i zaangażowaniu kobiet w sferę kultury.

Książka jest interesującą propozycją wydawniczą, adresowaną nie tylko do badaczy literatury i kultury czy historii, ale także do rozległego grona czytelników, zajmujących się tematyką żeńską i dziedzictwem narodowym. Przedstawione w Stowniku sylwetki kobiet to reprezentantki różnych dziedzin kultury: społecznej, duchowej, materialnej, to działaczki, aktywistki, kształtujące oblicze kulturalne, narodowe miasta, regionu, kraju, 
a w przypadku niektórych nawet - przestrzeni międzynarodowej, wnoszące wkład w całokształt dorobku. Do bardziej znanych i rozpoznanych portretów, zawartych w słowniku, należą, m.in: Izabela Branicka, Maria Konopnicka, Eliza Orzeszkowa, Nora Ney, Hanka Bielicka czy Anna Markowa. Do mniej znanych - m.in: Józefa Kisielnicka, Irena Białówna, Cecylia Piasecka, Kazimiera Żulińska czy Józefa Żdżarska. Oba tomy zawierają po 20 biogramów. Autorzy życiorysów skupiają uwagę na rolach, które wyznaczają rozmaicie skonstruowane natury kobiece. To dowodzi, że swoje wybory musieli poprzedzić wieloma drobiazgowymi analizami źródeł, postaci, rysując tym samym pewną perspektywę badawczą. Stopień szczegółowości biogramów jest różny, co powodowane było dostępnością źródeł i literatury przedmiotu, będących podstawą opracowań. W opisach przedstawiono zarówno szczegółowe informacje faktograficzne, jak i syntetyczne ujęcia najważniejszych wydarzeń, stanowiących podstawę działalności i życia wszystkich bohaterek. Wzbogacono je również o ikonografię czy materiały graficzne. Odsyłacze do źródeł i literatury przedmiotu pozwalają zainteresowanym odbiorcom na odnalezienie i doczytanie dodatkowych informacji. Z założenia jest to wybór unikalny i dobrze przemyślany. Tym samym słownik wpisuje się w tradycję studiów kobiecych. 